\title{
Aetiopathogenesis, Prevention and Management of Hypertension-An Ayurvedic View
}

\section{Abstract}

Hypertension is a common disease in present era. Every fifth person is found hypertensive. Most adults develop it, in later half of their life More than $50 \%$ of the deaths and disabilities from heart disease and stroke together kill more than 12 million people each year. It has been predicted that by the year 2020 there will be a $75 \%$ increase in the global cardiovascular disease burden occurring. In Ayurvedic texts there is no clear pronunciation of Hypertension; According to Charakacharya, sometimes neither it is possible nor it's necessary to identify a disease by a name (Anuktavyadhi). An Ayurvedic physician should attempt to construct the Samprapti (Pathogenesis) of a given clinical condition on the basis of signs, symptoms, acuteness, chronicity, complication with investigative findings in each case and should plan the management accordingly

Hypertension is dreadful disease which is multifactorial in its origin with a chronic aetio-pathogenesis when thought adapting the principle of Dosha, Dhatu and Mala theory the pathology seems to be centered on Shonita Dhatu and Tridosha So it fall in the Madhyam Rogamarga (intermediate route) \& hence it is Yapya disease (difficult to cure).

Keywords: Hypertension; Ayurveda; Shonita Dusti; Anuktavyadhi; Madhyam Rogamarga

\author{
Mini Review \\ Volume 9 Issue 5 - 2017 \\ Narayan S Jadhav ${ }^{1 *}$ and Shital D Ghorband ${ }^{2}$ \\ ${ }^{1}$ Department of Rognidan, V. V. Dhanwantari Ayurved Medical \\ College \& Hospital, India \\ ${ }^{2}$ Department of Dravyaguna, NKJAMC \& PGC, India \\ *Corresponding author: Narayan S Jadhav, Department \\ of Dravyaguna, Dhanvantari Ayurved Medical College \& \\ Hospital, Udgir Dist, Latur (M.S.), Bidar, (KA), India, Tel: \\ 09822675803; Email: drnarayanj52@gmail.com
}

Received: August 10, 2017 | Published: November 30, 2017

\section{Introduction}

Hypertension is a common disease in present era. Every fifth person is found hypertensive. Most adults develope it, in later half of their life [1]. It is one of the most frequent cause for cardiovascular, cerebrovascular and renovascular mortality and morbidity [2]. The adverse effects of hypertension principally involve the blood vessels, central nervous system, retina, heart and kidneys, and can often be detected clinically [1]. It is very well established that in case of untreated hypertension mortality and morbidity increase several fold and that control of it, reverse this to a great extent. So that hypertension must be treated and controlled [3], mainly in the developing countries. More than $50 \%$ of the deaths and disabilities from heart disease and stroke together kill more than 12 million people each year. It has been predicted that by the year 2020 there will be a $75 \%$ increase in the global cardiovascular disease burden occurring, The situation in India is rather more alarming, it has been predicted that there would be a $111 \%$ increases in the cardiovascular deaths in India by 2020 . Therefore cardiologist has already drawn considerable attention to the WHO and various health administrations to develop effective strategies for Hypertension Prevention Programme [1]. There is an urgent need to develop personalized medicine through traditional Ayurvedic medicine; a shift from single target single intervention approach to integrative system biology i.e. holistic approach.

In modern medicine anti hypertensive drugs lower the high blood pressure but do not eradicate the risk of cardio-cerebroreno-opthalmo-vascular involvement, But Ayurvedic therapy can minimize the risk factor in a better way. In Ayurvedic texts there is no clear pronunciation of Hypertension; but it might be present from the time, when life is existing in the universe because diseases like Pakshaghata (Stroke), Mutraghata(Renal failur) and Hridroga(Heart disease) are very well explained in our texts which are common complications secondary to Hypertension. It proves the existence of this silent killer from since old days [4].

\section{Nomenclature is Unresolved Question}

In this modern era there are several references available for the disease Hypertension in Ayurveda but we cannot justify authentically how the modern medical science have strong worldwide acceptance of word Hypertension. Here some different opinion by different Academicians of Ayurveda suggested different names to demonstrate the phenomenon like Raktagata vata (Y.N Upadhyaya-1950), Rakta Vikshepa ( J.P Shukla - 1954), Shiragata Vata (G.N Chaturvedi-1962), Avrita Vata ( R.K Sharma-1966), RaktaChapa (Ravani and Mahaishkar UB-1967), Rakta Sampida (S.B Pandey -1972), Vyana Bala (B.Triguna- 1974), Dhamani pratichaya (A.DAthawale), Dhamani Prapurnata (AD Athavale - 1977), Rasa Bhara (T.SAthawale-1979), RaktaVriddhi (G.N Chaturvedi-1981), RudhiraMada ( V.N Dwivedi- 1991), Raktavata (P.VSharma-1993) and list goes on with different concept by different Acharyas and it makes confusion to upcoming Ayurvedic generation, what could be taken? and what could not?. Until and unless we cannot accept this disease with its causative factors, Pathophysiology, Acuteness, Chronicity, Complications and exact treatment modalities universally [5]. 
According to Charakacharya, sometimes neither it is possible nor it's necessary to identify a disease by a name [1] an Ayurvedic physician should attempt to construct the Samprapti (Pathogenesis) of a given clinical condition on the basis of signs, symptoms and investigative findings in each case and should plan the management accordingly [7].

The disease Hypertension is abnormality of Rakta Dhatu, (Blood) and is popularly known as Shonit Dusti (Vitiated Blood). The unique category of clinical presentation comprising RaktaPitta. (Abnormal bleeding from different roots of the body) Rakta Pradara (excessive vaginal bleeding), RaktaMeha (Hematuria) etc. and Vat Rakta (Group of vascular disorders with Gouty Arthritis) and some of mucosal inflammations as Mukhapaka (Oral Ulcers), Akshiraga (Redness of Eyes) Upakushaand pootigrahaare also regarded maladies of Shonita Dusti (vitiation of blood).

Shiroruka (Headache) Klama (Nausea, Vomiting), Anidra (sleeplessness), Bhrma(imbalance of the body), Buddi Sammoha(Slugishness in Intelect), Kampa (Tremors) etc. Also it is interesting to note that all these symptoms are akin to manifestations of hypertension. More to add, Mada( Delerium), Moorcha (Stupor) and Sanyasa(Coma), the different diseases caused by Shonita Dushti (vitiation of blood) are described also as progressive manifestation of increasing Shonita Dushti. So also, such a sequele is equally true in relation to malignant Hypertension. All these deliberation corroborates parlance of the Shonitadusti and its different clinical manifestation of Mada Moorcha and Sanyasa to the essential Hypertension as well as Malignant Hypertension [8].

The essential hypertension when thought adapting the principle of Dosha, Dhatu and Mala theory pathology seems to be centered on Shonita Dhatu and Tridosha . there is a need to understand the cause, pathogenesis, acuteness, chronicity, complication and Symptomatology of the disease \& its holistic management.

\section{Regulation of Blood Pressure in Ayurveda}

Blood pressure is not described in any of the Ayurvedic classics. Blood pressure is an important phenomenon for the normal functioning of blood circulation, and physiology related to blood circulation is described by Ayurvedic Scholors. The regulation of Blood pressure is carried by Myocardial contractility, that pump the heart continuously and ejects the blood, helps in maintaining normal Blood pressure. In Ayurveda regulation of Blood pressure can be understood by functions of PranaVayu, Vyana Vayu, Sadhaka Pitta, Avalambaka Kapha, Rasa and Rakta Dhatu which are situated in Hridaya.( Heart).

According to Ranjit Rai Desai, vitiation of Vata, Pitta, and Kapha (Premordial factors), asthi meda etc. affects blood pressure Kapha vitiation (avalambak kapha) increases cardiac strength but due to sluggishness of kapha, it decreases the kapha and on other hand Pitta (sadhak pitta) and Vata (vyan vata) vitiation increases blood pressure. Here one thing must be clarified that term for blood circulation is not the rakta samvahana (transportation of blood) but rasanudhavana (Circulation of Plasma) Ayurveda belives that rasa(plasma) is the circulating medium and not the rakta(blood) [9].

\section{Etiology of Hypertension}

Essential Hypertension is idiopathic where exact etiology of the rise in blood pressure is not yet clear. There are many pre disposing factors which causes hypertension is mention as follow.

a. Alcohol intake (Madyapan)

b. Salt intake (Lavan)

c. Sedentary life style (Ati Snighda, Madhur \& Divaswap)

d. Mental Stress. (Krodha, Bhaya, Shok)

e. Physical Strain (Shrama)

f. Seasonal variations (Rutu Sandhi)

g. Nidanarthkara Roga - Madhumeha (Diabetes), Sthoulya (obesity), Hridroga (Heart disease), Vrika roga (Renal disease) are the precipitating diseases to form secondary hypertension [10].

\section{Pathogenesis of Hypertension in Ayurveda}

Ati lavana sevana (Exessive salt intake), madyapana (Alcohol consumption) snigdha bhojana ( oily diet) Divaswap (day time sleep) and manovighata (Mental accident) leads to vitiation of Shonita (blood). But Shonita being Dhatu (tissue) is not capable of vitiating Doshas (pre mordial factors of body) independently. The Doshas present in the Shonita which are involved indirectly in the manifestation of high blood pressure. The over use of salt, alcohol vitiates the Sadhaka pitta and Shonita(blood). Sedentary habits vitiate the Avalambaka kapha and psychological stress induces vitiation of Prana vayu. Initially Prana vayu gets prakopa. Since Prana vayu has influence on Hridaya(heart), vitiates Hridaya and its residing components like Vyana vayu, Sadhaka pitta, Avalambaka kapha. Shonita is also involved as it is located in hridaya.Prakupita (vitiated) Avalambaka kapha induces exaggerated contractility of the heart, while aggrevated Vyana vayu leads increased gati(speed), the force of ejection of blood from Hridaya. These events result into forceful expulsion of blood through dhamanis (blood vessels), ultimately leading into increased resistance in vessels ensuring High blood pressure.

\section{Samprapti ghatakas (components of pathogenesis)}

Doshas: Prana, Udan \& Vyana vayu, Sadhaka Pitta, Avalambaka Kapha (Premordial factors)

Manas Dosha: Raja, Tama

Dushyas: Rasa, Rakta, Mamsa, Meda (plasma, blood, Muscular \& Adipose tissues)

Updhatu: Sira, Dhamani (Blood Vessels)

Agni: Jatharagni-Dhatwagnimandya (Gastric Fire)

Aama: Rasagata (Toxins at plasma level)

Srotas (Channels): Rasavaha Raktavaha, Pranvaha \& Manovha (Circulatory\& Respiratory System)

Srotodushti Prakar-(type of lesion): Sanga type of srotorodha (obstruction) Udabhava Sthana- (site of occurance): Hridaya, Dhamani (heart \& blood vessels). 
Adhisthana (Location): Mano-daihika (physio-psychological) Sira, Dhamani, Srotas(blood vessels, body channels.

Sancharasthana (Transportation): Sarva Sharir (whole body)

Rogamarga(Diseaseroute): Madhyama Rogamarga(intermediate).

\section{Symptamatology (Lakshanas)}

Hypertension is asymptomatic in most of the cases but the symptoms can be seen in accelerated or sustained or Malignant Hypertension.

a. Headache (Shirorukh)

b. Tiredness (Shrama)

c. Irritability (Krodhaprachurata)

d. Raised body temperature (Jwara)

e. Dizziness (shirobhram)

f. Vomiting (Klama)

g. Altered consciousness (tamasaatidarshan)

h. Seizures (Kampa)

i. Visual Disturbances (Akshiraga)

j. Focal neurological signs (Ardita)

k. Urinary symptoms (Raktameha)

l. Delirium in Hypertensive (Shiro Bhrama)

m. Delirum in encephalopathy (Mada)

n. Stupor (Moorchha)

o. Coma (Sanyasa) [11].

\section{Prevention is Better than Cure}

The aim of Ayurveda is to promote the health by Preventive measures and further manage the disorder. The line of prevention and management of such disorder is beautifully quoted in Ayurveda.

a. Psychological up gradation

b. Life style and diet beneficial for heart.

c. Diet and exercise to facilitate srotas flow.

d. Follow the principles of peace (ahimsa)

e. Follow the path of knowledge (gyana) [12].

\section{How to Prevent Hypertension}

a. Stop smoking: Smoking or use of tobacco products are the most significant risk factors for heart disease which contains chemicals may be responsible for atherosclerosis.

b. Be physically active: It helps in control weight to reduce the chance of developing hypertension. Physical fitness can be achieved by increasing the intensity, duration and frequency of work outs such as gardening, housekeeping, use of stairs and mild to moderate morning walk for thirty minutes. c. Regular health screening: It is also an important way to prevent heart trouble "the earlier you start and treating it, the more disease you can prevent" Regular health check-ups or screening done by some simple parameters such as, measuring of blood pressure and blood test for LFT, KFT, Lipid profile, blood sugar and other basic features like BMI should be monitor regularly responsible for secondary hypertension.

d. Anti stress measures: Stress itself might be a risk factor, or it could be that high levels of stress make other risk factors worse. i.e. stress can cause high blood pressure, over eating, less physical activity. Chronic stress exposes your body to unhealthily, persistently elevated levels of the hormones like adrenaline and courtisol which increases the risk of heart attack [13].

e. Dietetic regimen: If the diet is pure, the heart will be pure. If the heart is pure the mind will be pure. If the mind is pure the intellect will be pure (manusmruti). As the food so the mind, as the mind so the man. As the food so the heart, as the heart so the man. (Bhagvadgita chapter.4) cardiologists blame that decline in the age growth of heart patients in India is due to the use of faulty food items (American heart association recommendations)

f. Fruits: (Apple, Chickoos, lemon, grapes, papaya and orange) are high source of vitamins and minerals along with low calories. Eating a lot of fruit and green vegetables controlling weight and blood pressure.

Fiber rich diet is the form of unrefined whole grain, water soluble dietary fibers can incorporated into diet \& result in significant lowering of cholesterol (4weeks) [14].

a. Omega 3 fatty acids can be gained by eating fish at least twice a week.

b. Avoid beverages and food that contain added sugars.

c. Avoid table salt or take low salt diet.

d. Regular intakes of some of the vitamins and minerals which may be associated with a healthy heart (chromium ,selenium, vitamin \& magnesium vitamin C and Calcium)

e. Barely butter milk, curd water, cow's urine, kanji (sour vinegar), tila taila etc [15].

\section{Principle of Management}

Ayurveda has certain limitations in the management of hypertension. Specially in the emergency treatment for the hypertensive crisis \& other vascular episodes. However Ayurveda can contribute significantly in the chronic hypertensive conditions. Where the precipitating factors are hyperlipidemia, obesity and other life style problems. The management of this condition is according to predominance of Dosha, intensity of symptoms and involved relevant target organ damage in the pathogeness [14].

\section{Management of Essential Hypertension}

It can be understand by various treatment modalities given for different conditions as follows: - Treatment of Rakta Pradosha, i.e. RaktaPittahar (Pacification of blood and Pitta Dosha) Herbal Medicine \& Diet. Virechana (Therapeutic Purgation), Upavasam (Fasting), Shonita Shravanam (Bloodletting) [6]. 
i. Vatapradhan Vatapitta: (Stress, Senility or Neurotic) Manobrimhan (Psychological up gradation and Murdhnitail. (Group of Procedures for Mental relaxation)

ii. Pitta pradhan Vatta pitta: (Alcoholic, Chr.smoker, Hyperthyroidism, polycypthemia vera, aggressive personality, hepatic disorders) - Virechana (Pitta \& Mutra virechan), Raktamokshan (bloodletting).

iii. Kapapradhan Vatta kapha - (hyper lipidemia, atherosclerosis, obesity or cardio vascular disorders) -Panchkarma Therapies- Vamana (therapeutic vomiting), Virechana (therapeutic purgation), Lekhan Basti( medicated enema), Medohar (lipid lowering) drugs. A combination of these three is also possible. A single line diagnosis and treatment not help to tackle the problem.

\section{Management of Secondary Hypertension}

a. Renal hypertension - Mutraghat Chikitsa( T/t of Renal failure) - Gokshur, Punarnva, Kasni, Shilajit.

b. Endocrine disorders - Cushing syndrome, phaeochromocytoma and acromegaly - Pitta Shamak \& Agni Deepak Chikitsa.

Therapeutic Management [17]

\begin{tabular}{|c|c|}
\hline Hridya & Haritaki, Arjuna, Hridya maha kashaya \\
\hline Srotasprasadana & Guggulu, pushkarmula, Kustha \\
\hline Ojasya & $\begin{array}{c}\text { Nagabala, Jivaniya varga, Vayasthapak, } \\
\text { Kakolyadigana }\end{array}$ \\
\hline Manasa Prasadana & $\begin{array}{c}\text { Brahmi, Shankapushi, Rudraksha, } \\
\text { Sarpagandha }\end{array}$ \\
\hline
\end{tabular}

Life Style Management [17]

\begin{tabular}{|c|c|}
\hline $\begin{array}{c}\text { Metabolic } \\
\text { Correction }\end{array}$ & $\begin{array}{c}\text { Triphala / Ghrita, Louki, Haritaki, Vacha, } \\
\text { Rasna, Pippali, Sunthi, Puskar Moola, } \\
\text { Katuki }\end{array}$ \\
\hline Physical Support & $\begin{array}{c}\text { Daily routine, seasonal routine, } \\
\text { Panchakarma, Rasayana, Vajikarna }\end{array}$ \\
\hline Mental Support & $\begin{array}{c}\text { Avoid conflict, emotion, Mediation - Yoga } \\
\text { including Pranayam }\end{array}$ \\
\hline
\end{tabular}

\section{Conclusion}

It can be concluded that by understanding the aetiopathogenesis of hypertension. We can provide prevention and treatment of the condition by, Nidan Parivarjan (avoid etiological factors), Pathya Apathya (do \& donts), Shamana (pacification) \& Shodhan (biopurification), Rasayan (immunomodulatory), and Vajikaran Chikitsa. (aphrodiasiac treatment)). Hypertension is dreadful disease which is multifactorial in its origin with a chronic aetio-pathogenesis. So it falls in the Madhyam Rogamarga (intermediate route) \& hence it is Yapya disease (difficult to cure).

There is no clear clue regarding the hypertension in Ayurvedic text. a. It is a psychosomatic hemodynamic disease with a multifactorial pathology of several dietary, environmental and genetic factors.

b. Life style modification, stress management is essential for a maintenance of normal homeostasis and also blood pressure.

\section{Acknowledgment}

None.

\section{Conflict of Interest}

None.

\section{References}

1. Ambulkar P, Chand T, Rao S, Dwivedi L (2010) Makardhwaj as a Boon in Hypertension (Vyan Bala Vaishamya): A Clinical Evalution, Proceedings in National Seminar on Preventive Cardiology in Ayurveda. Rashtriya Ayurveda Vidyapeeth Publication, New Delhi, India, pp. 295-300.

2. Tripathi A (2010) Clinical evaluation of Shankhapuspi compound in Hypertension, Proceedings in National Seminar on Preventive Cardiology in Ayurveda. Rashtriya Ayurveda Vidyapeeth Publication, New Delhi, India, pp. 309-313.

3. Yadav B, Sehrawat D, Prasad M, Ghosh S (2010) A clinical study on factors affecting prevalence of Hypertension (Raktagatvat): Proceedings in National Seminar on Preventive Cardiology in Ayurveda. Rashtriya Ayurveda Vidyapeeth- Publication, New Delhi, India, pp. 269-278.

4. Shukla N, Shukla CP (2010)A Comparative study of Sarpagandhavati and Vachadiyoga in the management Essential Hypertension; Proceedings in National Seminar on Preventive Cardiology in Ayurveda, R.A.V. Publication, New Delhi, India, pp. 251-258.

5. Rathod MR, Sharma Amit Kumar (2012) Understanding of Hypertension in Ayurveda. J Altem and Integ Med 1: 494.

6. Tripathi B, Samhita C, Adhyaya S (2012) 18(44-47)P-378. In: Chakarpani \& Charak Chandrika (Eds.), Chaukhamba Surbharati Prakashan, Varanasi, India.

7. Ambika Dutta Shashtri Sushruta Samhita (1995) Nidanasthana Adhya 1(45-46). (9 $9^{\text {th }}$ edn), Varanasi, India. p. 463.

8. Astanga Hridaya: Sutrasthana 27/3-4. Ayurveda Rasayana and Sarvanga Sundara.

9. Desai R (2010) Ayurvediya Kriyasharir, Chaukhamba Surbharati Prakashan, Varanasi, India.

10. Tripathi B, Samhita C, Adhyaya S (2012) 24(5-10) P-430. In: Chakarpani \& Charak Chandrika (Eds.), Chaukhamba Surbharati Prakashan, Varanasi, India.

11. Tripathi B, Samhita C, Adhyaya S 24(11-17) P-430. In: Chakarpani \& Charak Chandrika (Eds.), Chaukhamba Surbharati Prakashan. Varanasi, India.

12. Charmi S Mehta (2012) Management of Hypertension in Ayurved. Rasamruta 4: 1

13. Tripathi B, Samhita C, Adhyaya S (2012) 30(13-14) P-561. In: Chakarpani \& Charak Chandrika (Eds.), Chaukhamba Surbharati Prakashan, Varanasi, India. 
14. Sherawat, Yadav B, Prasad M (2010) Prevention and Management of Cardiac Disorders through Ayurveda: Proceedings in National Seminar on Preventive Cardiology in Ayurveda. R.A.V. Publication, New Delhi, India, p. 233-239.

15. Tripathi B, Samhita C, Achaia C (2012) 26/81-82) P-880. In: Chakarpani \& Charak Chandrika (Eds.), Chaukhamba Surbharati Prakashan. Varanasi, India.

16. Tripathi B, Samhita C, Adhyaya S (2012) 24(18) P-431. In: Chakarpani \& Charak Chandrika (Eds.), Chaukhamba Surbharati Prakashan. Varanasi, India.
17. Debnath PK (2010) Preventive Cardiology in Ayurveda Enabling Nirmal Hridaya; Proceedings in National Seminar on Preventive Cardiology in Ayurveda. R.A.V. Publication, New Delhi, India. p. 6062. 